\title{
Myostatin genotype regulates muscle-specific miRNA expression in mouse pectoralis muscle
}

Satyanarayana Rachagani, Ye Cheng, James M Reecy*

\begin{abstract}
Background: Loss of functional Myostatin results in a dramatic increase in skeletal muscle mass. It is unknown what role miRNAs play in Myostatin mediated repression of skeletal muscle mass. We hypothesized that Myostatin genotype would be associated with the differential expression of miRNAs in skeletal muscle.

Findings: Loss of functional Myostatin resulted in a significant increase $(p<.001)$ in miR-1, miR-133a, miR-133b, and miR-206 expression. In contrast, Myostatin genotype had no effect $(P>.2)$ on miR-24 expression level.

Myostatin genotype did not affect the expression level of MyoD or Myogenin ( $P>0.5)$.

Conclusions: Myostatin may regulates the expression of miRNAs such as miR-133a, miR-133b, miR-1, and miR-206 in skeletal muscle as it has been observed that the expression of those miRNAs are significantly higher in myostatin null mice compared to wild type and heterozygous mice. In contrast, expression of myogenic factors such as MyoD or Myogenin has not been affected by myostatin in the muscle tissue.
\end{abstract}

\section{Background}

miRNAs have generated strong interest among researchers in different fields to understand their biosynthesis, mechanism of action, and identification of their targets. First discovered in the caenorhabditis elegans as small temporal RNAs required for proper developmental timing, miRNA are a family of highly conserved, noncoding, 22 nucleotide [1] double-stranded RNA products that post-transcriptionally regulate gene action [1-4].

Sampere et al. (2004) first identified the expression of the muscle specific miRNas such as miR-1, -133a and -206 [5]. Their expression was highly enriched in both human and mouse heart and skeletal muscle. Subsequently, several miRNA expression profiling studies have consistently shown $m i R-1,-133 a$ and -206 to be muscle specific [6-11]. These muscle specific expressions are evolutionarily conserved among animals [12]. Over expression of $m i R-1$ and $m i R-133$ during the in-vitro development of embryoid bodies from mouse embryonic stem cells demonstrated that distinct steps in muscle development are specified by cooperative and opposing interactions between $m i R-1$ and $m i R-133$.

Given that miRNAs have been shown to play roles in the regulation of satellite cell proliferation and

\footnotetext{
* Correspondence: jreecy@iastate.edu

Department of Animal Science, lowa State University, Ames, lowa, USA
}

differentiation, the current study was carried out to evaluate the effect of loss of Myostatin function on skeletal muscle miRNA expression.

\section{Methods}

\section{Animal Experimentation}

The present experiment was conducted with mice that were $\mathrm{MSTN}^{-/-}$[13], $\mathrm{MSTN}^{+/+}$and $\mathrm{MSTN}^{+/-}$(either sex). $\mathrm{MSTN}^{+/-}$mice were mated to produce $\mathrm{MSTN}^{-1-}$ $(\mathrm{n}=9), \mathrm{MSTN}^{+/+}(\mathrm{n}=10)$ and $\mathrm{MSTN}^{+/-}(\mathrm{n}=10)$ animals. The mice were housed in a temperature- and humidity-controlled room and maintained at $22^{\circ} \mathrm{C}$ on a 12-h light-dark cycle with food and water provided ad libitum. At 1 week of age, mice were individually identified and genotyped. Mice were weaned at 21 days of age. At 35 days of age mice were euthanized by $\mathrm{CO}_{2}$ asphyxiation. The pectoralis muscles were excised, flashfrozen in liquid nitrogen, and stored at $-80^{\circ} \mathrm{C}$ until RNA isolation. The Iowa State University Institutional Animal Care and Use Committee approved all procedures that involved mice.

\section{DNA Isolation and Genotyping}

The DNA was isolated by standard protocol with few modifications [14] from toes clipped at seven days after birth. Myostatin genotyping was completed with a 
three-primer PCR reaction. The primer sequences were: Mstn1-5'-GGC ATC TGT TCT GCT ATT ACG TGC3',Mstn2-5'-GTG CGA TAA TCC AGT CCC AT-3' and Mstn3-5'-GTG GAT GTG GAA TGT GTG CGA GG3'. The PCR amplification reaction contained $50 \mathrm{ng}$ DNA, $0.2 \mu \mathrm{l}(50 \mathrm{pmol})$ of each primer, $5 \mu \mathrm{l}$ of $2 \mathrm{X}$ Green GoTaq ${ }^{\oplus}$ Reaction Buffer (pH 8.5) (GoTaq ${ }^{\circ}$ DNA Polymerase, $400 \mu \mathrm{M}$ dATP, $400 \mu \mathrm{M}$ dGTP, $400 \mu \mathrm{M}$ dCTP, $400 \mu \mathrm{M}$ dTTP and $3 \mathrm{mM} \mathrm{MgCl} 2$ ). The PCR amplification was carried out in a programmable thermal cycler (MJ research) using the following program: 3 minutes at $92^{\circ} \mathrm{C}, 15$ seconds at $92^{\circ} \mathrm{C}, 30$ seconds at $65^{\circ} \mathrm{C}, 30 \mathrm{sec}-$ onds at $72^{\circ} \mathrm{C}$ followed by 39 cycles of 15 seconds at $92^{\circ} \mathrm{C}, 30$ seconds at $65^{\circ} \mathrm{C}, 30$ seconds at $72^{\circ} \mathrm{C}$, final extension of 10 minutes at $72^{\circ} \mathrm{C}$. The PCR products were size separated on $1.5 \%$ agarose gels to confirm genotype based on the amplification of target regions.

\section{RNA Isolation}

Total RNA was isolated from left pectoralis muscle using TRIzol reagent (Invitrogen, Carlsbad, CA, USA) according to manufacturer's directions. The RNA was purified by columns (Qiagen sciences, Maryland, USA) and treated with DNase I (Qiagen, Maryland, USA) to remove genomic DNA contamination. The RNA concentration was measured by UV absorbance. RNA samples with an $A_{260 / 280}$ ratio of $=>2.0$ were used for RTPCR.

\section{cDNA Synthesis and Real Time PCR for MYOD and Myogenin}

Reverse transcription of RNA was performed (Invitrogen, Carlsbad, CA) by adding $10 \mu \mathrm{l}$ of (500 $\mathrm{ng}$ ) total RNA, $1 \mu \mathrm{l}$ of Oligo (dT) $12-18(500 \mu \mathrm{g} / \mathrm{ml})$, and $1 \mu \mathrm{l} 10$ $\mathrm{mM}$ dNTP incubated at $65^{\circ} \mathrm{C}$ for 5 minutes and immediately chilled on ice. Then, each component was added in the indicated order $4 \mu \mathrm{l}$ of $(5 \times)$ first strand RT buffer, $0.1 \mathrm{M}$ DTT $1 \mu \mathrm{l}$, RNaseOUT. RNase Inhibitor $1 \mu \mathrm{l}$, incubated at $42^{\circ} \mathrm{C}$ for $2 \mathrm{~min} .1 \mu \mathrm{l}$ (50 units) of SuperScript II RT was then added to each tube mix, and incubated at $42^{\circ} \mathrm{C}$ for $50 \mathrm{~min}$. The reactions were terminated at $70^{\circ} \mathrm{C}$ for $15 \mathrm{~min}$. Chill on ice.

Real-time PCR was performed on Stratagene 4000x Real-Time PCR System. Quantitative PCR reactions were optimized for annealing temperature and primer concentration. Real-time PCR reactions were performed in triplicate and template controls (NTCs) were run for each assay under the same conditions. End-point PCR was then performed in $10 \mu \mathrm{l}$ reaction containing $5 \mu \mathrm{l}$ SBYR green Master Mix, $3.2 \mu \mathrm{l}$ of autoclaved nuclease free water, $1 \mu$ l diluted RT product (Minimum1:10 but MyOD undiluted cDNA was used) and $0.4 \mu$ f forward and reverse primers (specific to genes i.e MyoD
F-5'-TACAGTGGCGACTCAGATGC-3' and R-5'GCTCC ACTATGCTGGACAGG-3' and MyoG F-5'-CTACAGGCCTTGCTCAGCTC-3' and R-5'ACGATGGACGTAAGGGAGTG-3') for 40 cycles (two steps: $95^{\circ} \mathrm{C}$ for 10 minutes followed by 40 cycles $95^{\circ} \mathrm{C}$ $15 \mathrm{~s}$ followed by $58^{\circ} \mathrm{C}$ for $60 \mathrm{~s}$ ). Standard curves were generated with known amounts (molecules) of cDNA and run with each PCR run. Gene expression levels were normalized to the level of $\beta$-actin expression, which we have shown to be unresponsive to Myostatin expression level [15], and are reported relative to Myostatin wild-type expression level.

\section{Detection of Mature miRNAs by TaqMan assays}

Five mouse Taqman miRNA assays were purchased from Applied Biosystems. Reverse transcription reactions $(15 \mu \mathrm{l})$ containing, $1.5 \mu \mathrm{l}$ of $10 \times$ reverse transcription buffer, $1.0 \mu \mathrm{l}$ of MultiScribe ${ }^{\mathrm{Tm}}$ reverse transcriptase (50 U/ $\mu \mathrm{l}$ ), $0.15 \mu \mathrm{l}$ of $100 \mathrm{mM} \mathrm{dNTPs} \mathrm{(with} \mathrm{dTTP)} \mathrm{and}$ $0.19 \mu \mathrm{l}$ of RNase inhibitor $(20 \mathrm{U} / \mu \mathrm{l}), 4.16$ of Nucleasefree water were mixed by brief centrifugation, $5 \mu \mathrm{l}$ of total RNA (50 ng) was added and mixed well, $3 \mu \mathrm{l}$ of $1 \times$ looped-primers were added (specific for microRNA) and mixed well and incubated for $30 \mathrm{~min}$ each, at $16^{\circ} \mathrm{C}$, $42^{\circ} \mathrm{C}$ and 5 minutes at $85^{\circ} \mathrm{C}$ according to manufacturer's directions. The cDNA was diluted to a minimum of 1:15 with nuclease free water and $1.33 \mu \mathrm{l}$ was used in real time PCR.

Real-time PCR was performed on Stratagene 4000x Real-Time PCR System. During the target amplification step, the AmpliTaq ${ }^{\circ}$ Gold DNA polymerase amplifies target cDNA synthesized from the RNA sample, using sequence-specific primers from the TaqMan Assay. Real-time PCR reactions based on TaqMan reagent chemistry were performed in triplicate and template controls were run for each assay under the same conditions. End-point PCR was then performed in $20 \mu \mathrm{l}$ reactions that contained $10.00 \mu \mathrm{l}$ TaqMan $2 \times$ Universal PCR Master Mix No AmpErase UNG, $7.67 \mu \mathrm{l}$ of autoclaved nuclease free water, $1.33 \mu \mathrm{l}$ diluted RT product (Minimum1:15) and $1 \mu \mathrm{l}$ miRNA-specific PCR probe for 40 cycles (two steps: $95^{\circ} \mathrm{C}$ for 10 minutes followed by 40 cycles $95^{\circ} \mathrm{C} 15 \mathrm{~s}$ followed by $60^{\circ} \mathrm{C}$ for $60 \mathrm{~s}$ ). miRNA expression levels were normalized to the level of $m i R-24$ expression, which was unresponsive to Myostatin expression level, to correct for differential cDNA content.

\section{Statistical analysis}

Student's $t$-test was used to determine whether a significant difference existed among $\mathrm{MSTN}^{-/-}, \mathrm{MSTN}^{+/-}$and $\mathrm{MSTN}^{+/+}$animals. The $P<0.05$ was denoted by an asterisk. 


\section{Findings}

Pectoralis muscles from 29 mice were examined for differential expression of five microRNAs and two genes. The weight of $\mathrm{MSTN}^{-/-}$pectoralis muscle $(108 \pm 5.9$ $\mathrm{mg})$ was significantly greater $(\mathrm{p}<0.001)$ than $\mathrm{MSTN}^{+/+}$ pectoralis muscle $(72.6 \pm 5.9 \mathrm{mg}) 35$ days after birth.

\section{Expression of muscle-specific miRNAs and myogenic factors}

The expression level of $m i R-133 a(\mathrm{p}<0.0001), m i R-$ $133 b(\mathrm{p}<0.001), \operatorname{miR}-1(\mathrm{p}<0.001)$, and $m i R-206(\mathrm{p}<$ $.0001)$ was greater in Myostatin-null animals as compared to wild type and heterozygous animal (Figure 1). In all cases, the expression level of miRNAs was equivalent in $\mathrm{MSTN}^{+/-}$and $\mathrm{MSTN}^{+/+}$muscle. In contrast, $m i R-24$ expression level was not affected by Myostatin genotype (data not shown). Myostatin genotype had no significant effect on the expression level of MyoD or Myogenin (Figure 2).

\section{Discussion}

Accumulating evidence supports a role for miRNAs in the regulation of myogenesis [16]. $m i R-1 /-206$ and
miR-133 play opposing roles in modulating skeletal muscle proliferation and differentiation. The miR-1 and $m i R-206$ promote myogenesis, while $m i R-133$ inhibits myoblast differentiation and promotes proliferation by repressing serum response factor and a key splicing factor [17-20].

In this study, we observed higher miR-1, miR-133a, $m i R-133 b$, and $m i R-206$ expression levels in the pectoralis muscle of $\mathrm{MSTN}^{-/-}$mice as compared to $\mathrm{MSTN}^{+/+}$ and $\mathrm{MSTN}^{+/-}$animals. This increased level of $m i R-1$, $-133 a,-133 b$, and -206 expressions was consistent with the enhanced skeletal muscle growth observed in $\mathrm{MSTN}^{-1-}$ mice. In order to sustain the increased growth observed in Myostatin-null mice elevated satellite cell proliferation, which is regulated by miR-133 [19] and differentiation, which is regulated by $m i R-1$ and -206 $[19,19,21]$, must occur. However, this would also indicate that the increased levels of miRNA would need to occur in a cell-type specific manner.

Recently, Davis et al. (2008) reported that SMAD proteins control Drosha-mediated miRNA maturation. They observed that TGF- $\beta$ and BMP4 treatment promoted the formation of specific miRNA/SMAD complexes,

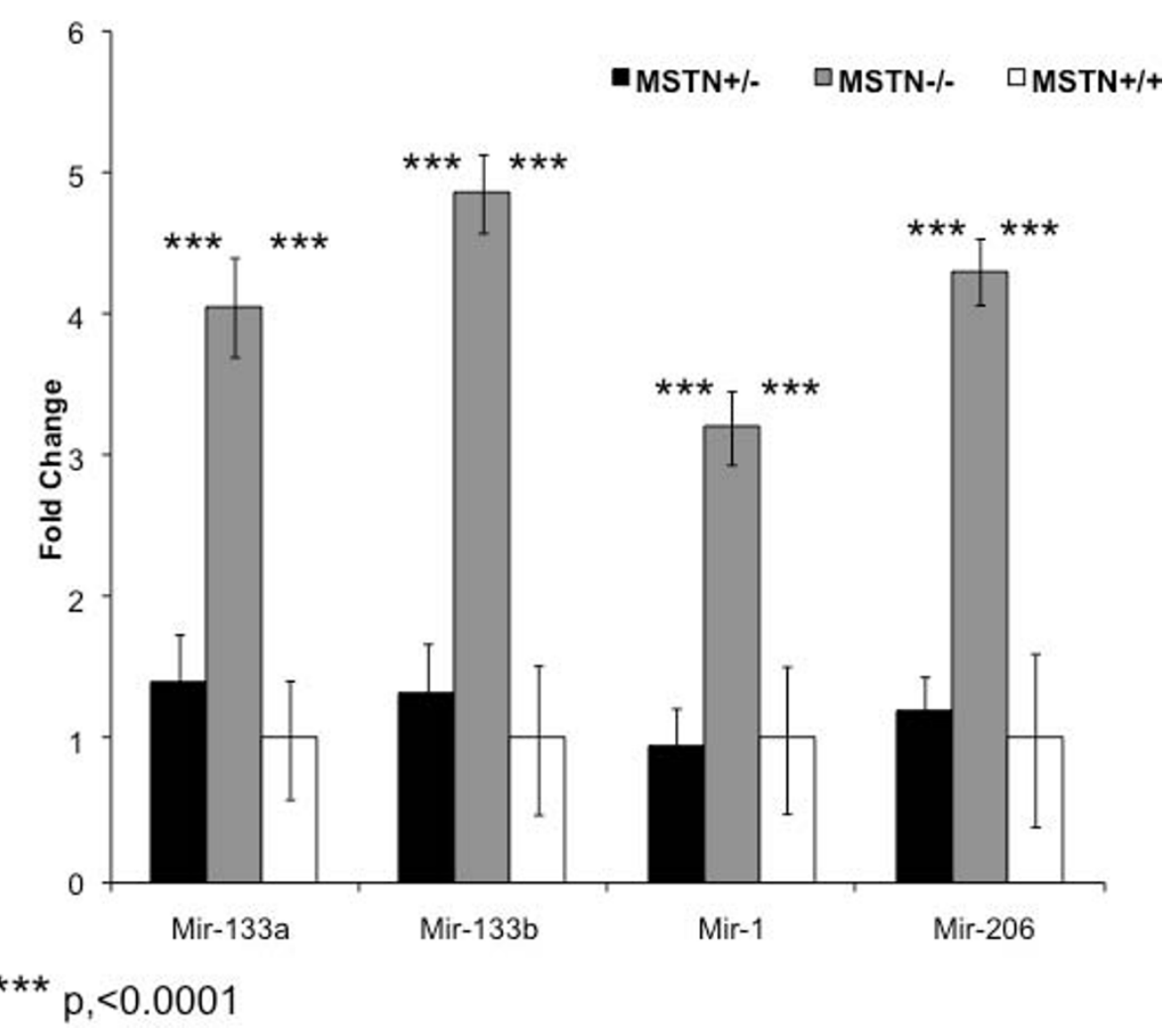

Figure 1 Relative expression of mature microRNAs in the mouse pectoralis muscle. Real-time PCR expression values were normalized to miR-24 and then reported relative to MSTN $^{+/+}$levels. Data are means \pm S.E. ${ }^{* * *} p,<0.0001$. MSTN $+/+$ is a wild-type mouse, MSTN $-/+$ represents a heterozygous Myostatin-null mouse, and MSTN -/- represents a homozygous Myostatin-null mouse. 


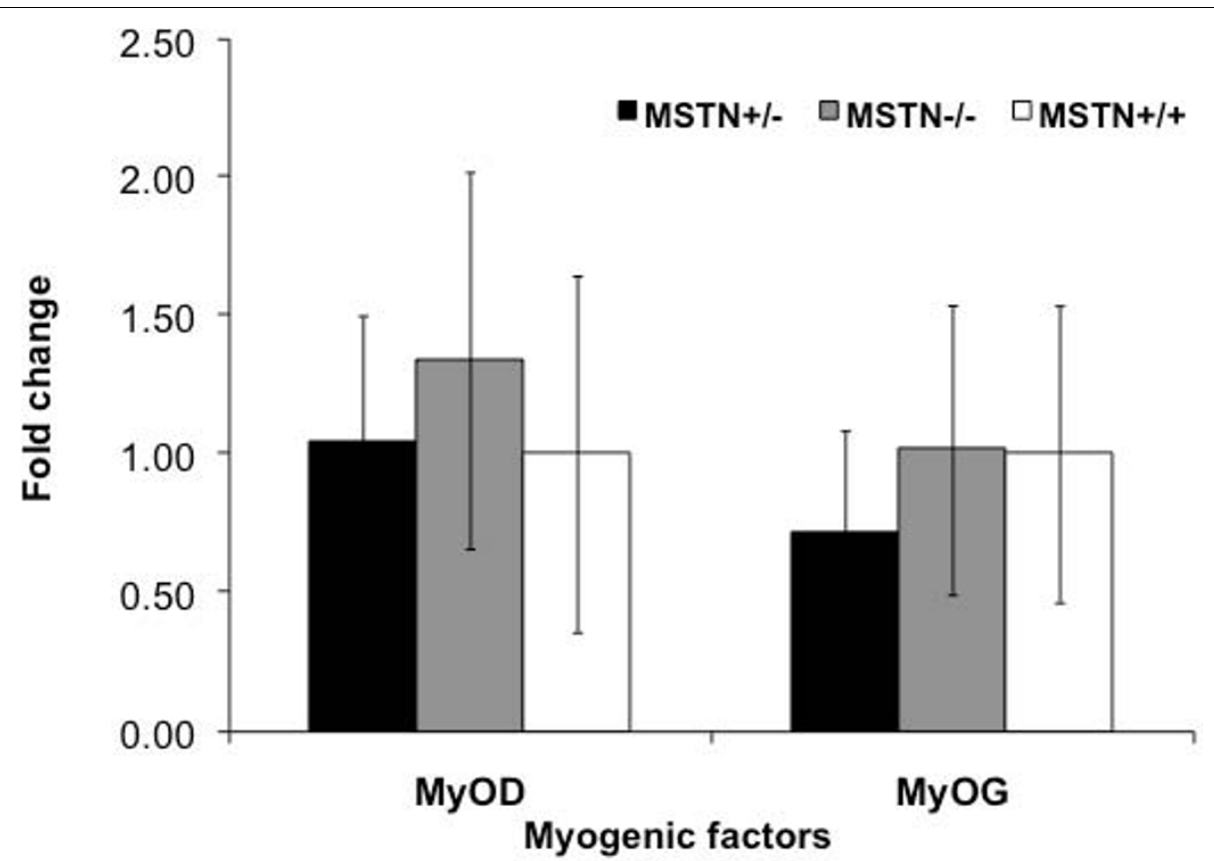

Figure 2 Relative expression of myogenic factors in the mouse pectoralis muscle. Real-time PCR expression values were normalized to $\beta$ actin and are reported relative to $\mathrm{MSTN}^{+/+}$levels. The graph represents the mean $( \pm \mathrm{SE})$ fold change in gene expression.

which facilitated miRNA maturation. In contrast, we observed increased mature miRNA levels in the absence of functional Myostatin, which is a TGF- $\beta$ super family member. This observation indicates the possibility that TGF- $\beta$ super family member can both promote and inhibit maturation of specific miRNAs [22].

Alternatively, the increased miRNA expression observed in the absence of functional Myostatin could be the result of enhanced Myf5 and MEF2A gene expression. Previously, we reported that loss of functional Myostatin increased both Myf5 and MEF2A gene expression [15]. Recently, Sweetman et al. (2008) reported that over expression of Myf5 was capable of inducing $m i R-1$ and $m i R-206$ [23]. While, miR-1 and miR-206 expression was lost in $\mathrm{Myf5}^{-1-}$ mice, which indicates that miR-1 and miR-206 lie downstream of Myf5. Similarly, Liu et al. (2007) identified an intragenic MEF2-dependent enhancer that directed miR-1 and miR-133a expression levels. Thus, it is possible that the observed increase in muscle-specific miRNAs is the result of increased Myf5 and MEF2A expression, which are the result of loss of functional Myostatin [24].

Interestingly, none of the miRNAs exhibited an additive expression level with the increasing loss of Myostatin (ie. miRNA expression in heterozygotes should be intermediate between Myostatin-null and wild-type). Myostatin appears to control miR-1, $-133 a,-133 b$, and -206 in a dominant manner, as the presence of functional Myostatin (wild-type and heterozygous mouse muscle) similarly regulated miRNA expression. Given that skeletal muscle mass was increased in heterozygous Myostatin mice, this would seem to indicate that $m i R-1$, $-133 a,-133 b$, and -206 are not required for the observed increased muscle mass observed in Myostatin-null and heterozygous mice. Alternatively, it is also possible that $m i R-1,-133 a,-133 b$, and -206 are very sensitive to Myostatin and even low levels of Myostatin, such as those observed in $\mathrm{MSTN}^{+/-}$mice, can inhibit their expression. Thus, it is possible that miR-1, $-133 a,-133 b$, and -206 are necessary for the increased muscle mass observed in Myostatin-null mice, but they are not rate limiting.

\section{Conclusions}

The expression of miR-133a ( $\mathrm{p}<.0001)$, miR-133b $(\mathrm{p}<$ $.001), \operatorname{miR}-1(\mathrm{p}<.001)$, and $m i R-206(\mathrm{p}<.0001)$ were significantly higher in myostatin null mice compared to wild type animals. Therefore, myostatin may regulate the expression of miRNAs in skeletal muscle. Similarly, myostatin has no effect on expression of myogenic factors such as MyoD or Myogenin in the muscle tissue.

\section{Abbreviations}

dATP: 2'-deoxyadenosine 5'-triphosphate; CCTP: 2'-deoxycytosine 5'triphosphate; dGTP: 2'-deoxyguanosine 5'-triphosphate; dTTP: 2'-

deoxythymidine 5'-triphosphate; $\mathrm{MgCl}_{2}$ : Magnesium chloride; MSTN: Myostatin; PCR: Polymerase chain reaction; RT: reverse transcriptase; MSTN$^{-1}$ : homozygous myostatin null mice; $\mathrm{MSTN}^{+/}$: heterozygous mice at myostatin locus; $\mathrm{MSTN}^{+/+}$: wild type at myostatin locus 


\section{Acknowledgements}

This work was funded by a grant from the United State Department of Agriculture (2007-04187). This journal paper of the lowa Agriculture and Home Economics Experiment Station, Ames, lowa (Project No. NRSP-8) was supported by Hatch Act and State of lowa funds.

\section{Authors' contributions}

SR contributed to, performed the breeding, genotyping of mouse, Real time PCR and Taqman assays and prepared the manuscript. YC contributed to the analysis of the data. JMR was responsible for the design of research and the manuscript. All authors read and approved the final manuscript.

\section{Competing interests}

The authors have no conflict of interest with any company or financial organization.

Received: 12 June 2010 Accepted: 11 November 2010

Published: 11 November 2010

\section{References}

1. Lee RC, Feinbaum RL, Ambros V: The C. elegans heterochronic gene lin-4 encodes small RNAs with antisense complementarity to lin-14. Cell 1993, 75:843-854.

2. Ambros V: The functions of animal microRNAs. Nature 2004, 431:350-355

3. Bartel DP: MicroRNAs: genomics, biogenesis, mechanism, and function. Cell 2004, 116:281-297.

4. Pasquinelli AE, Reinhart BJ, Slack F, Martindale MQ, Kuroda MI, Maller B, Hayward DC, Ball EE, Degnan B, Muller P, et al: Conservation of the sequence and temporal expression of let-7 heterochronic regulatory RNA. Nature 2000, 408:86-89.

5. Sempere LF, Freemantle S, Pitha-Rowe I, Moss E, Dmitrovsky E, Ambros V: Expression profiling of mammalian microRNAs uncovers a subset of brain-expressed microRNAs with possible roles in murine and human neuronal differentiation. Genome Biol 2004, 5:R13.

6. Shingara J, Keiger K, Shelton J, Laosinchai-Wolf W, Powers P, Conrad R, Brown D, Labourier E: An optimized isolation and labeling platform for accurate microRNA expression profiling. RNA 2005, 11:1461-1470.

7. Baskerville S, Bartel DP: Microarray profiling of microRNAs reveals frequent coexpression with neighboring miRNAs and host genes. RNA 2005, 11:241-247.

8. Chen CZ, Lodish HF: MicroRNAs as regulators of mammalian hematopoiesis. Semin Immunol 2005, 17:155-165.

9. Kim HK, Lee YS, Sivaprasad U, Malhotra A, Dutta A: Muscle-specific microRNA miR-206 promotes muscle differentiation. J Cell Biol 2006, 174:677-687.

10. Beuvink I, Kolb FA, Budach W, Garnier A, Lange J, Natt F, Dengler U, Hall J, Filipowicz W, Weiler J: A novel microarray approach reveals new tissuespecific signatures of known and predicted mammalian microRNAs. Nucleic Acids Res 2007, 35:e52.

11. Liang $Y$, Ridzon D, Wong $L$, Chen C: Characterization of microRNA expression profiles in normal human tissues. BMC Genomics 2007, 8:166-166.

12. Nguyen $H T$, Frasch M: MicroRNAs in muscle differentiation: lessons from Drosophila and beyond. Curr Opin Genet Dev 2006, 16:533-539.

13. McPherron AC, Lawler AM, Lee SJ: Regulation of skeletal muscle mass in mice by a new TGF-beta superfamily member. Nature 1997, 387:83-90.

14. Laird PW, Zijderveld A, Linders K, Rudnicki MA, Jaenisch R, Berns A: Simplified mammalian DNA isolation procedure. Nucleic Acids Res 1991, 19:4293.

15. Steelman CA, Recknor JC, Nettleton D, Reecy JM: Transcriptional profiling of myostatin-knockout mice implicates Wnt signaling in postnatal skeletal muscle growth and hypertrophy. FASEB J 2006, 20:580-582.

16. Zhao Y, Samal E, Srivastava D: Serum response factor regulates a musclespecific microRNA that targets Hand2 during cardiogenesis. Nature 2005, 436:214-220

17. Kim HK, Lee YS, Sivaprasad U, Malhotra A, Dutta A: Muscle-specific microRNA miR-206 promotes muscle differentiation. I Cell Biol 2006, 174:677-687.

18. Rosenberg Ml, Georges SA, Asawachaicharn A, Analau E, Tapscott SJ: MyoD inhibits Fst11 and Utrn expression by inducing transcription of miR-206. J Cell Biol 2006, 175:77-85.
19. Chen JF, Mandel EM, Thomson JM, Wu Q, Callis TE, Hammond SM, Conlon FL, Wang DZ: The role of microRNA-1 and microRNA-133 in skeletal muscle proliferation and differentiation. Nat Genet 2006, 38:228-233.

20. Boutz PL, Chawla G, Stoilov P, Black DL: MicroRNAs regulate the expression of the alternative splicing factor $\mathrm{nPTB}$ during muscle development. Genes Dev 2007, 21:71-84.

21. Kim HK, Lee YS, Sivaprasad U, Malhotra A, Dutta A: Muscle-specific microRNA miR-206 promotes muscle differentiation. J Cell Biol 2006, 174:677-687.

22. Davis BN, Hilyard AC, Lagna G, Hata A: SMAD proteins control DROSHAmediated microRNA maturation. Nature 2008, 454:56-61.

23. Sweetman D, Goljanek K, Rathjen T, Oustanina S, Braun T, Dalmay T, Munsterberg A: Specific requirements of MRFs for the expression of muscle specific microRNAs, miR-1, miR-206 and miR-133. Dev Biol 2008, 321:491-499.

24. Liu N, Williams AH, Kim Y, McAnally J, Bezprozvannaya S, Sutherland LB, Richardson JA, Bassel-Duby R, Olson EN: An intragenic MEF2-dependent enhancer directs muscle-specific expression of microRNAs 1 and 133. Proc Natl Acad Sci USA 2007, 104:20844-20849.

doi:10.1186/1756-0500-3-297

Cite this article as: Rachagani et al:: Myostatin genotype regulates muscle-specific miRNA expression in mouse pectoralis muscle. $B M C$ Research Notes 2010 3:297.

\section{Submit your next manuscript to BioMed Central and take full advantage of:}

- Convenient online submission

- Thorough peer review

- No space constraints or color figure charges

- Immediate publication on acceptance

- Inclusion in PubMed, CAS, Scopus and Google Scholar

- Research which is freely available for redistribution

Submit your manuscript at www.biomedcentral.com/submit
C Biomed Central 